\title{
STRENGTHENING SURVEY OF ENVIRONMENTAL CARE ATTITUDES TO SUPPORT THE ADIWIYATA PROGRAM FOR HIGH SCHOOL GRADE XI IPS STUDENTS NEGERI 02 SINTANG REGENCY
}

\author{
Norsidi ${ }^{1}$ \\ ${ }^{1}$ Geography Education, Faculty of Education and Social Knowledge \\ IKIP-PGRI Pontianak \\ E-mail: habibisukma1991@gmail.com
}

\begin{abstract}
This study aims to determine the strengthening of environmental care attitude to support the adiwiyata program of students of class XI IPS Sintang District 02 High School. This type of research is survey research which is included in the quantitative category. Therefore, this study uses a sample of one population and uses a questionnaire as an instrument of data collection. The subjects of this study were students of class XI IPS in State High School 02 Sintang Regency, amounting to 30 people. Analyzing data is based on the calculation of the percentage of results of filling out questionnaires by respondents. The results obtained are as follows: 1) the role of students in strengthening environmental caring attitudes through the adiwiyata program, namely with an average value of $43 \%$ with sufficient categories. 2) the form of implementation in strengthening environmental awareness through adiwiyata program with an average value of 49\%, with sufficient categories. 3) Constraints faced by students in strengthening environmental awareness through adiwiyata program with an average value of 59\%, with sufficient categories.
\end{abstract}

Keywords: Environment, Adiwiyata Program, Geography Education.

\section{A. INTRODUCTION}

School is an institution or place for students to carry out the process of teaching and learning activities to receive knowledge from teachers in accordance with levels ranging from elementary school (SD), junior high school (SMP) and high school (high school). Schools are formal educational institutions that systematically carry out guidance, teaching and training programs in order to help students to be able to develop their potential, both those involving moral, spiritual, intellectual, emotional, and social aspects (Syamsu, 2002).

A clean and beautiful school environment is expected by all school residents to facilitate a comfortable teaching and learning process. Schools as special institutions that have a vehicle to support a caring attitude to the environment. The learning process of Environmental Education that is carried out should be a process of organizing values and clarifying concepts to foster the skills and attitudes needed to 
understand and appreciate human relations, culture and physical environment (Desfandi, 2015).

RI Law No. 32 of 2009 concerning the Environment that the environment is a unity of space with all objects, power, conditions and living things, including humans and their behavior, which affect nature itself, as well as the continuity of life, and the welfare of humans and other living things. Environmental education can help the community especially students to be aware of the importance of protecting the environment. The attitude of caring for the environment must be applied early on to the community, especially the school environment so that students get knowledge about environmental education. Krnel \& Naglic [2009], and Pauw \& Van Petergem [2013] showed that Eco School program is fail/less effective in enhancing students' knowledge, attitude and care toward environment.

A caring attitude towards the environment is very important for students. According to Neoloka, (2008: 19) environmental awareness is an effort that involves every citizen in growing and fostering awareness to preserve the environment based on values, namely the values of the environment itself with the philosophy of living peacefully with the natural environment. Awareness of environmental care attitudes must be developed towards students so that the values of awareness can be applied in everyday life. One of the ideas of the program is to realize an environmentally conscious attitude and care through the implementation of the adiwiyata program in schools.

Based on the Regulation of the Minister of Environment of the Republic of Indonesia (2013: 2) the adiwiyata program is a program to create a school that is environmentally friendly and cultured. The adiwiyata program is carried out in elementary school (SD) to high school (SMA) education. The aim of the adiwiyata program is to make school residents responsible for protecting and managing the environment through good school governance to support sustainable development. With this adiwiyata program, it can help students and all school members that the importance of caring for the environment.

State Senior High School 2 (SMA) 2 Sintang Regency is very suitable to be applied to learning about environmental care behavior by being continuously implanted through habituation through the adiwiyata program. However, habituation is hampered because the attitude of students care about the environment is still lacking. There are 
still lots of plastic rubbish strewn around the small trench in front of the class and there are also cigarette sheds in the toilet. Another problem was found that some of the desks, chairs and walls were crossed out by students with ballpoint pens. To realize environmental care behavior it is not enough to involve only one modifying aspect or certain parties (for example schools only) to make changes but by considering all aspects involved and cooperation between all parties (Iswari \& Suyud, 2017).

The need for readiness of the State Senior High School 2 Sintang District to prepare the adiwiyata program to foster an environment of caring attitude for students of class XI IPS. The Adiwiyata program is implemented to realize school members who are responsible for environmental protection and management efforts through good school governance to support sustainable development (Desfandi, 2015). The environment is all external, physical, and biological factors that directly affect the survival, growth, development, and reproduction of organisms, while what is meant by the environment is the unity of space with all objects, power, conditions, and living things, including in it human beings and their behavior, which affect the continuity of life and human well- being of all other living things (Mustofa, 2000).

\section{B. MATERIALS AND METHODS}

The approach used in this study is a quantitative descriptive approach that is research that describes the variables, symptoms or circumstances and information obtained from research subjects. Most of the information will be realized in the form of numbers. This study aims to determine the attitude of caring for the environment to support the adiwiyata program for class XI IPS students of SMA Negeri 02 Sintang Regency. This type of research is survey research that is included in the quantitative category. Survey research is research that takes a sample from one population and uses a questionnaire as a primary data collection tool (Masri, 1995). This study uses a sample from one population using a questionnaire as an instrument for data collection. The subjects of this study were students of class XI IPS 3, amounting to 30 people using purposive random sampling techniques. Ali (1993) states that this sampling technique is based on a particular consideration made by the researcher himself, based on the characteristics or characteristics of the population that have been known previously. Analysis and interpretation 
of data based on the calculation of the percentage of results filled out by the respondent's questionnaire.

\section{RESULTS AND DISCUSSION}

1. The Role of Students in Strengthening Environmental Care Attitudes Through the Adiwiyata Program of Class XI IPS 3 Sintang District 2 High School

Based on the results of the processing and research analysis of the role of students in strengthening environmental care attitudes through the XI IPS adiwiyata program, Sintang District 2 High School as follows:

Table 1. Strengthening

Environmental Care Attitudes

Through the Adiwiyata Program

\begin{tabular}{|c|c|c|}
\hline No & Statement Items & Percentage \\
\hline 1 & A1 & $35 \%$ \\
\hline 2 & A2 & $38 \%$ \\
\hline 3 & A3 & $64 \%$ \\
\hline 4 & A 4 & $43 \%$ \\
\hline 5 & A5 & $47 \%$ \\
\hline 6 & A6 & $35 \%$ \\
\hline 7 & A7 & $34 \%$ \\
\hline 8 & A 8 & $41 \%$ \\
\hline 9 & A9 & $44 \%$ \\
\hline 10 & A10 & $47 \%$ \\
\hline \multicolumn{2}{|c|}{ Overall percentage } & $43 \%$ \\
\hline
\end{tabular}

Item A1 questions participate in maintaining classroom cleanliness with an average value of $35 \%$ which is categorized as less. From this there are still students who disagree because there are still many students who are negligent in their duties and responsibilities in maintaining class cleanliness. Item A2 questions about participating in cleaning the school environment with an average value of $38 \%$ which is categorized as less. From this it can be seen that students have a feeling of being lazy to clean the school so that it looks less bold and neat. Item A3 questions about participating in cleaning school toilets with an average value of $64 \%$ categorized as good. From these results, it seems that students have an awareness to play an active role in maintaining the cleanliness of the toilet.

A4 question items feel obliged to take environment-based extracurricular activities with an average value of $43 \%$ which is categorized sufficient. From this, students are not very active in participating in environment-based activities to foster a sense of caring for the school environment. A5 question items participate in green groups in schools with an average score of $47 \%$ which is categorized as sufficient. From this it shows that students still care to look after the environment. Item A6 realizes that it is necessary to create a clean and comfortable school environment with 
an average value of $35 \%$ which is categorized as less. From this, most students are less concerned and less aware that they have an important role in creating a clean and comfortable school environment.

Item question A7 Indicators concerning realizing the need to create health in the school environment with an average value of $34 \%$ are categorized as less. From this, students do not have the awareness to maintain a clean and healthy environment. Item A8 questions regarding that garbage can be recycled with an average value of $41 \%$ which is categorized as sufficient. From this, students do not understand how to recycle according to the type and function of waste. Item A9 questions believe that it can choose organic and inorganic waste with an average value of $44 \%$ which is categorized as sufficient. From this, students can distinguish organic and inorganic waste. The item A10 question about believing that it can utilize waste is an economically valuable product with an average value of $47 \%$ which is categorized as sufficient. From this, students understand that garbage can be processed into something valuable that has a sale value.
The results of processing and analysis of research data obtained results in a percentage value of $43 \%$ which was categorized sufficient. Based on these results, students of class XI IPS in Sintang District 2 High School understand the important role of creating a clean school environment climate. However, there are still students who are negligent in their duties and responsibilities in maintaining class cleanliness. Most students are less caring and less knowledgeable to encourage the creation of a clean school environment because students have a feeling of being lazy to clean the school so that it looks less bright and neat. It needs to be reaffirmed the purpose of actual education, including environmental education that is integrated in the Adiwiyata Program. Environmental education must focus on changing individual behavior rather than just changing understanding because what is more important is building the soul and character of individuals who are in accordance with religious and moral values (Iswari \& Suyud, 2017). 
2. Implementation of Strengthening Environmental Care Attitudes Through the Adiwiyata Program for Class XI IPS 3 of Sintang District 2 High School

Based on the results of processing and data analysis the form of implementation of the value of environmental care values of XI IPS students in Sintang District 2 SMA as follows:

Table 2. Results of the Questionnaire in the Form of Implementation on Strengthening the Attitude of Environmental Care Through the Adiwiyata Program

\begin{tabular}{|c|c|c|}
\hline No & Statement Items & Percentage \\
\hline 1 & $\mathrm{~B} 1$ & $47 \%$ \\
\hline 2 & $\mathrm{~B} 2$ & $40 \%$ \\
\hline 3 & $\mathrm{~B} 3$ & $35 \%$ \\
\hline 4 & $\mathrm{~B} 4$ & $43 \%$ \\
\hline 5 & $\mathrm{~B} 5$ & $73 \%$ \\
\hline 6 & $\mathrm{~B} 6$ & $42 \%$ \\
\hline 7 & $\mathrm{~B} 7$ & $77 \%$ \\
\hline 8 & $\mathrm{~B} 8$ & $46 \%$ \\
\hline 9 & $\mathrm{~B} 9$ & $53 \%$ \\
\hline 10 & $\mathrm{~B} 10$ & $36 \%$ \\
\hline \multicolumn{2}{|c|}{ Overall percentage } & $49 \%$ \\
\hline
\end{tabular}

In item B1, always take care of plants according to the schedule in the school environment with an average value of $49 \%$ with sufficient categories. From these results students take care of plants in the school environment in an effort to provide the beauty of the school environment. B2 question items about turning off fans and lights when learning ends with an average value of $40 \%$ typed less. The results show that high school students do not have the awareness to turn off the fan and turn off the lights after the lesson ends. Item B3 questions dispose of garbage in its place with an average value of $35 \%$ less categories. From these results, there are still students who throw garbage in the places provided.

Item B4 participates in voluntary work activities at the end of each semester with an average score of $43 \%$, which is categorized as sufficient. From these results students participate in community service activities to create a clean school environment. Item B5 scattered waste is common with an average value of $73 \%$ categorized as high. From this it is shown by the amount of garbage scattered which results in the cleanliness of the school environment not maintained because students are less concerned about the environment.

Item B6 questions using the sink well with an average value of $42 \%$, students of class XI IPS 3 agree that they must maintain school facilities properly, some students of class XI IPS 3 can use the sink well. Item B7 often eats in class and discards the wrapper on the bench with an average value of $77 \%$ 
categorized as high. From this, students still often eat in class and throw trash under the table so that class cleanliness is not maintained. Item question B8 participates in tree planting around the school environment with an average score of $46 \%$ which is categorized sufficient. From this, students participate in tree planting so that the school environment is not arid.

Item Question B9 participates in making a plant maintenance schedule in the school environment with an average value of $53 \%$ which is categorized as sufficient. From this it can be seen that students play a role in the care of plants by helping to make plant maintenance schedules around the school. Item B10 questions clean the class according to the picket schedule with an average value of $36 \%$ which is categorized sufficient. From this it can be seen that the caring attitude of students towards class cleanliness is still lacking so that the state of the class is dirty.

The results of processing and analysis of research data obtained a percentage of the overall value of $54 \%$ which is categorized sufficient. But there are still students who have the awareness to turn off the fan and lights when learning ends. In addition, students still do not have the awareness to dispose of garbage in its place so that the amount of garbage is scattered which results in poor hygiene in the school environment. This was triggered by many students after eating throwing trash under tables and chairs so that class cleanliness did not look neat.

\section{Constraints Faced by Students on} Strengthening Environmental Care Attitudes Through the Adiwiyata Program in Class XI IPS 3 of Sintang District 2 High School

Based on the results of the research data processing and analysis, the students' constraints on strengthening environmental care attitudes through the XI IPS class adiwiyata program at Sintang District 2 SMA as follows:

Table 3. Student Constraints on Strengthening Environmental Care Attitudes Through the Adiwiyata

Program

\begin{tabular}{|c|c|c|}
\hline No & Statement Items & Percentage \\
\hline 1 & $\mathrm{C} 1$ & $36 \%$ \\
\hline 2 & $\mathrm{C} 2$ & $81 \%$ \\
\hline 3 & $\mathrm{C} 3$ & $41 \%$ \\
\hline 4 & $\mathrm{C} 1$ & $56 \%$ \\
\hline 5 & $\mathrm{C} 2$ & $60 \%$ \\
\hline 6 & $\mathrm{C} 3$ & $70 \%$ \\
\hline 7 & $\mathrm{C} 1$ & $73 \%$ \\
\hline 8 & $\mathrm{C} 2$ & $65 \%$ \\
\hline 9 & $\mathrm{C} 3$ & $56 \%$ \\
\hline 10 & $\mathrm{C} 1$ & $55 \%$ \\
\hline \multicolumn{2}{|c|}{ Overall percentage } & $59 \%$ \\
\hline
\end{tabular}


In item question $\mathrm{C} 1$ the sense of responsibility of students in carrying out class picket schedules with an average value of $36 \%$ is categorized as less. From this it can be seen that there are obstacles in carrying out class pickets because students arise from feeling lazy only some who diligently clean the class. C2 question items feel forced when carrying out class pickets with an average value of $81 \%$ categorized as high. From this, students have problems because they feel forced to carry out class pickets. These problems are caused by class picking scheduled after completion of learning activities. At this hour students want to go home quickly because they are hungry and immediately want to take a nap because of the density of activities at school.

Item question $\mathrm{C} 3$ provides facilities for caring for plants in schools with an average value of $41 \%$ categorized as sufficient. From this, it can be seen that equipment for caring for plants in schools is minimal so that they have few obstacles in caring for plants. The question item $\mathrm{C} 4$ is limited land for reforesting schools with an average value of $56 \%$ categorized as sufficient. From this, it appears that land is available but has not been used for schooling. Item C5 questions regarding the limited knowledge of students about environmental management with an average value of $60 \%$ are categorized sufficient. From this it can be seen that students understand about environmental management.

Item C6 question, there is no routine activity involving students related to the value of environmental care with an average value of $70 \%$ categorized as high. From this, students are less involved by the school in relation to environmental activities because the school has not made the program structured to care for the environment. Item questions C7 students damage existing facilities in schools with an average value of $73 \%$ categorized as high. From this, the facilities or tools needed to clean the environment are damaged. The C8 question items students scribbled on the classroom walls with an average value of $65 \%$ categorized as high. From this, students still write a lot on the walls of the school building so that the class is not maintained and is not neat. 
Item $\mathrm{C} 9$ questions regarding the limited knowledge of students about the procedures for caring for school environment plants with an average value of $56 \%$ is sufficient. From this, it is seen that students are still limited to caring for schooling because of a lack of knowledge in caring for the school environment. The item C10 question is limited to the exemplary attitude to care for the environment of the school teacher with an average value of $55 \%$ which is categorized sufficient. From this it can be seen that the teacher has given a good enough example to behave caring for the environment well. The teacher is the main character in the development of character caring for the students' environment during the teaching and learning activities taking place (Mohammad \& Fathurahman, 2017).

The results of the research questionnaire as a whole obtained an average value of $59 \%$ categorized as sufficient. However, there are still obstacles to applying environmental care to support the adiwiyata program. Students have a sense of laziness to carry out class pickets. Sometimes students feel compelled to carry out class pickets because the schedule is applied after the learning activity has finished. At this time the students are hungry and there is a desire to quickly go home immediately to rest because of the density of activities at school. In addition, students also do not understand about environmental management because there is no routine program activities in a structured way to care for the environment. This results in students doing deeds to cross out the walls of the school building so that the classroom is not maintained and less neat. This is triggered by the behavior of humans who care less about their environment which causes the condition of the natural environment to become increasingly alarming (Fadila \& Elfyetti, 2017).

\section{CONCLUSIONS}

Based on the results of the study strengthening the environmentally caring attitude to support the adiwiyata program of XI IPS students at State High School 02 Sintang Regency with the following indicators: 1) the role of students in strengthening environmental care attitudes through the adiwiyata program which is an average value of $43 \%$ with enough categories; 2) the form of implementation in strengthening environmental awareness through 
adiwiyata program with an average value of $49 \%$, with sufficient categories; 3) Constraints faced by students in strengthening environmental awareness through adiwiyata program with an average value of $59 \%$, with sufficient categories.

\section{E. REFERENCES}

Desfandi, M. (2015). Mewujudkan Masyarakat Berkarakter Peduli Lingkungan Melalui Program Adiwiyata. Jurnal Social Science Education, 51-57.

Fadila, A., \& Elfyetti. (2017). Analisis Sikap Peduli Lingkungan Siswa Melalui Program Adiwiyata Di SMA Negeri 01 Medan. Jurnal Geografi, 125-312.

Iswari, R. D., \& Suyud, W. U. (2017). Evaluasi Penerapan Program Adiwiyata Untuk Membentuk Perilaku Peduli Lingkungan di
Kalangan Siswa. Jurnal Ilmu Lingkungan, 35-41.

Krnel, D \& Naglic, S, (2009). Environmental Literacy Comparison Between EcoSchools and Ordinary Schools in Slovenia. Science Education International, Vol. 20, No.1/2, December 2009, 5-24

Masri, S. (1995). Metode Penelitian Survei. Jakarta: LP3S.

Mohammad, D., \& Fathurahman, B. (2017). Pelaksanaan Program Adiwiyata Dalam Mendukung Pembentukan Karakter Peduli Lingkungan di SMA Negeri 4 Pandeglang. Jurnal Pendidikan Geografi, 25-36.

Mustofa. (2000). Kamus Lingkungan. Jakarta: Rineka Cipta.

Neoloka. (2008). Kesadaran Lingkungan. Jakarta: Rineka Cipta.

Syamsu, Y. (2002). Psikologi Perkembangan Anak \& Remaja. Bandung: Remaja Rosdakarya. 